REVIEWS

UDC 577.21

\title{
Model DNA for investigation of mechanism of nucleotide excision repair
}

\author{
A. N. Evdokimov ${ }^{1,2}$, O. I. Lavrik ${ }^{1,2,3}$, I. O. Petruseva ${ }^{1}$ \\ ${ }^{1}$ Institute of Chemical Biology and Fundamental Medicine, Siberian Branch of the Russian Academy of Sciences \\ 8, Akad. Lavrent'eva Ave., Novosibirsk, Russian Federation, 630090 \\ ${ }^{2}$ Altai State University, Ministry of Education and Science of the Russian Federation \\ 61, Lenina Ave., Barnaul, Russian Federation, 656049 \\ ${ }^{3}$ Novosibirsk State University, Ministry of Education and Science of the Russian Federation \\ 2, Pirogova Str., Novosibirsk, Russian Federation, 630090 \\ irapetru@niboch.nsc.ru
}

\begin{abstract}
The living cell DNA is under permanent attack of a variety of exogenous and endogenous damaging factors. Nucleotide excision repair (NER) is main pathway which removes a wide variety of bulky DNA adducts formed by UV light, electrophilic environmental mutagens, and chemotherapeutic agents. NER process in mammalian cells consistently leads to the very specific excision of damaged DNA fragments 24-32 nucleotides in length. The following DNA repair synthesis and DNA ligation restore intact DNA helix. The main set of the genes inactivated in NER-deficient higher eukaryotic cells was identified; about 30 proteins are involved in the specific multi-subunit complexes responsible for NER process. The specific NER feature is wide substrate specificity and great difference of damages elimination efficiencies. A key limiting step in NER is damage recognition and verification. One of the advanced and upcoming approaches to NER process investigation is based on the application of model DNAs - artificial DNA structures, which are analogs of substrate or intermediates of the repair process. This article reviews our current knowledge concerning the model DNA design, synthesis and application as a tool for the NER process comprehensive study.
\end{abstract}

Keywords: nucleotide excision repair, bulky DNA adducts, model DNA.

Introduction. The DNA of the living cells is subject of various modifications due to the impact of both exogenous and endogenous factors. There are several ways of damaged DNA repair in order to prevent the accumulation of modifications and to protect the genetic information in cells. The nucleotide excision repair (NER) is one of the most important ways to achieve genome safety. NER protects the cells from the broadest range of structurally and chemically different bulky DNA damages. The damages are present in the form of modifica tions of nitrogenous bases, occurring due to the effect of UV light, ionizing radiation, environmental electrophilic chemical mutagens, some medical drugs as well as chemically active endogenous metabolites,

(C) Institute of Molecular Biology and Genetics, NAS of Ukraine, 2014 including reactive derivatives of oxygen and nitrogen. In the cells of higher eukaryotes the NER system with high precision removes oligonucleotide fragments 24 32 nucleotides in length, containing the damage [1]. The subsequent reparative synthesis using the non-damaged strand as a template, followed by the ligation of the single-strand break, complete the process of DNA repair [2] (Fig. 1). The main genes, inactivated in NERdeficient cells of higher eukaryotes, have been identified and the protein factors and enzymes have been determined. This process is known to be performed by coordinated activity of about 30 proteins, subsequently forming on DNA complexes of variable composition [3]. The mutations in the genes, encoding these proteins, lead to the down regulation of the NER process. Such mutations result in some diseases, including xe- 


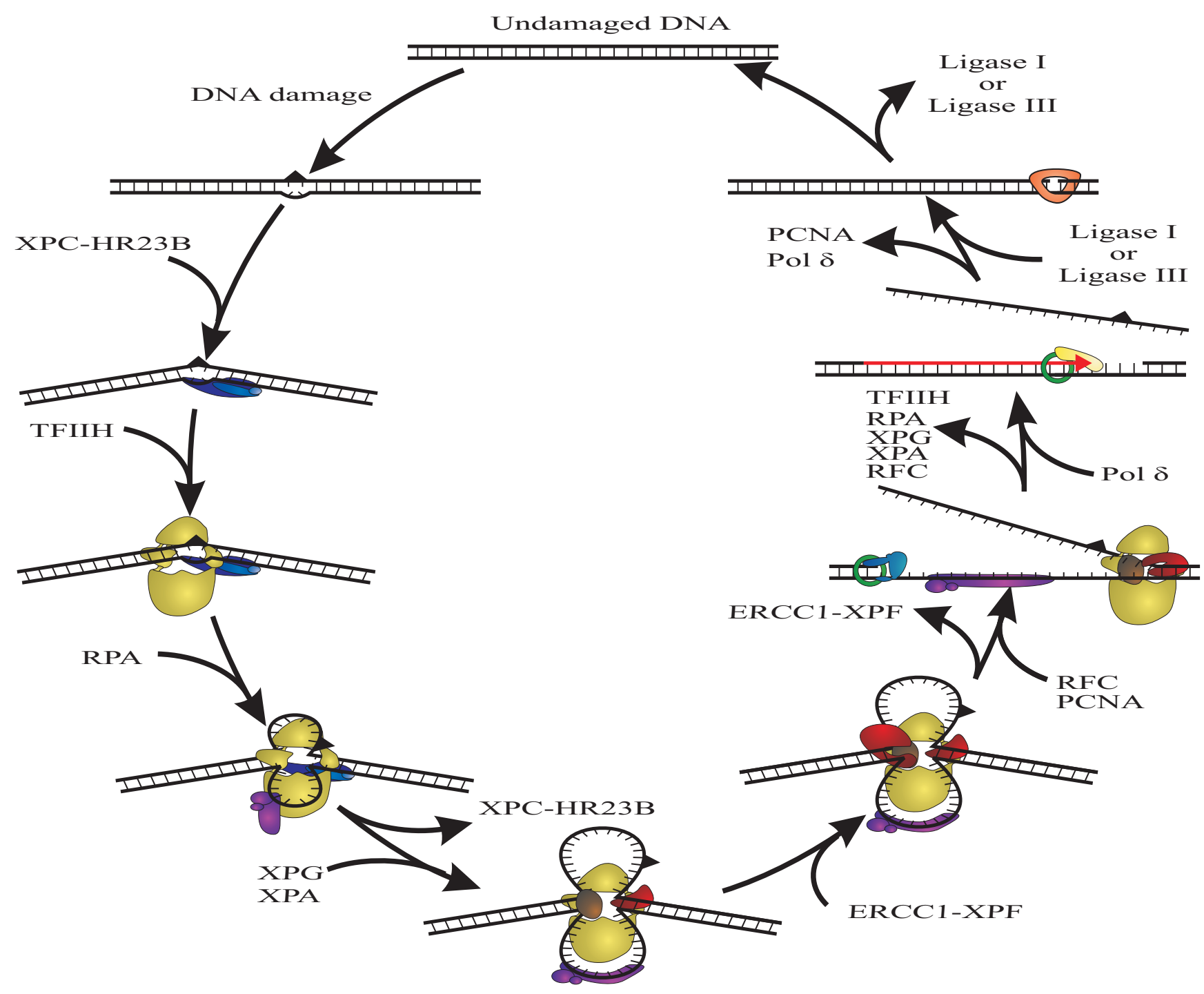

Fig. 1. Scheme of global genome nucleotide excision repair

roderma pigmentosum (XP), Cockayne syndrome (CS) and trichothiodystrophy (TTD), characterized by UVsensitivity, high risk of cancer and a number of neurodegenerative symptoms [4].

There are two variants of NER process, differing at the damage recognition step. The signal for the start of the transcription-coupled repair (TCR) is the stop of RNA-polymerase, when the damage in the transcribed DNA strand arrests the transcription activity $[5,6]$. Global genome nucleotide excision repair (GG-NER) performs the searching and removal of the bulky damages regardless of the functional state of the genome, including the non-transcribed parts of chromatin. The specia- lized sensor factors - XPC (protein complex XPC/ HR23B/Cen2) and XPE (DDB1/DDB2 heterodimer, promoting the recognition of UV-damage) are responsible for the primary recognition of the damage in the GG-NER process [1, 7-10].

A broad range of biochemical and molecular biology methods, including the methods, based on the application of artificial model DNAs, are used for the detailed study of the mechanism of the interaction between NER protein factors among themselves and with the DNA in vitro.

Generally the model DNAs are either the analogues of the substrate (of the damaged DNA) or the analogues 


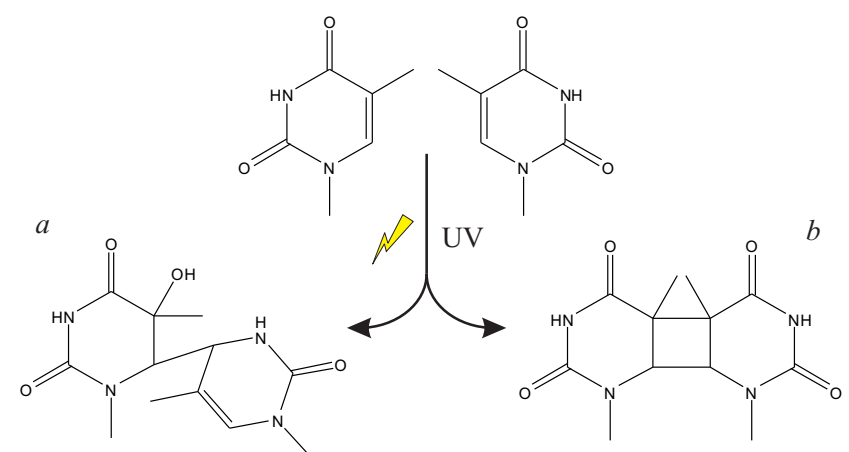

Fig. 2. DNA UV irradiation products - pyrimidines dimers: $a-$ 6-4-photoproducts; $b$ - cyclobutane pyrimidines dimers

of the intermediates of the NER process. In particular, these intermediates are modified duplexes, containing artificially introduced non-complementary parts («bubbles» of different length), «fork»-like structures, as well as some structures, containing $5^{\prime}$ or 3 '-overhangs [11-14].

The main types of damages, repaired by the NER system and the modifications, used for model DNA synthesis. Regardless of the fact that the model DNA has been used to study the NER process for many years, the elaboration and improvement of the methods for the model DNA synthesis still remains actual. Different bulky lesions obtained due to the modification of nitrogenous bases are used as a damage-mimicking adducts, repaired by the NER system. Such adducts may imitate the structure of damages that appear in cellular DNA under exogenous or endogenous damaging factors. On the other hand, these lesions may be artificial constructions, the introduction of which into dsDNA also leads to the distortion in its structure and the change in the thermodynamic stability.

The products of $U V$ irradiation. One of the main DNA-damaging agents is UV radiation. It was determined that UV light is the most dangerous for the organism part of the sunlight, reaching the surface of the Earth. The UV spectrum is composed of three parts: UV A (300-400 nm), UV B (290-320 nm) and UV C (200$290 \mathrm{~nm}$ ) with the highest energy, but it is mainly filtered out by the ozone layer of the Earth. The maximal formation of the photoproducts is observed when DNA is exposed to UV light at the wavelength lesser than $300 \mathrm{~nm}$. It is in good agreement with the adsorption spectrum of the main DNA chromophores - thymine and cytosine. Prokaryotes and lower eukaryotes are capable of remove UV-damages using the NER system.
Additionally, they can repair UV-lesions by the specific enzymes - photolyases, transforming pyrimidine dimers into the intact monomers [15]. In contrast, in higher eukaryotes cells UV-damages only can be removed by NER system.

Pyrimidine dimers (Fig. 2), the UV-radiation products, are the most common model of pyrimidine damage.

Cyclobutane pyrimidine dimers (CPD) (Fig. 2, b) are formed due to $(2+2)$ cyclo attaching along double bonds $\mathrm{C} 5-\mathrm{C} 6$ of adjacent pyrimidine bases. The majority of CPD are formed by adjacent TT bases, but the formation of these adducts is also possible due to the interaction of CC, CT or TC depending on the wavelength, radiation dose and nucleotide sequence. The formation of CPD is reversible after the impact of UV-light at the wavelength of $250 \mathrm{~nm}$ [16].

6-4-photoproducts (Fig. 2, a) are included in the number of the most common UV-damages in the cell [17]. The intermediate, obtained due to $(2+2)$ attaching, is regrouped with the formation of 6-4-photoproduct which with further radiation may be reversed into the Dewar isomer. In contrast with CPD, 6-4-photoproducts cause higher distortion of the DNA structure with the disturbance of nucleotide coupling at the site of the damage, which is reflected in higher efficiency of their repair by the NER system $[18,19]$.

The products of environmental chemical agents. Polycyclic aromatic hydrocarbons (PAH) are widespread environmental pollutants, which are the products of incomplete combustion of different materials. Benzo[a]pyrene and benzo[c]-anthracene are inert non-polar compounds. However in the process of metabolic detoxification in the mammals, involving cytochrome $\mathrm{C}$ and epoxyhydrolases action, potentially toxic lipophilic PAH molecules transform not only into excreted soluble derivatives, phenols and dihydrodioles, but also into electrophilic, chemically active diolepoxides, capable to stereoselective reacting with nucleobases with the formation of bulky adducts [20]. The repair of benzo[a]pyrene damages has been studied in details. The methods of synthesis of the DNA, containing dG- and dAbenzo[a]-pyrene adducts with different structure and stereochemistry, are developed. Analysis of repair process of such model DNA, along with the results of instrumental methods of analysis and computer simula- 
a<smiles>Nc1ccc2ccccc2c1</smiles><smiles>Nc1ccc(-c2ccccc2)cc1</smiles><smiles>Nc1ccc(-c2ccc(N)cc2)cc1</smiles>

$b$<smiles>CC(=O)Nc1cc2c(cc1Nc1nc3c(ncn3C)c(=O)[nH]1)-c1ccccc1C2</smiles>

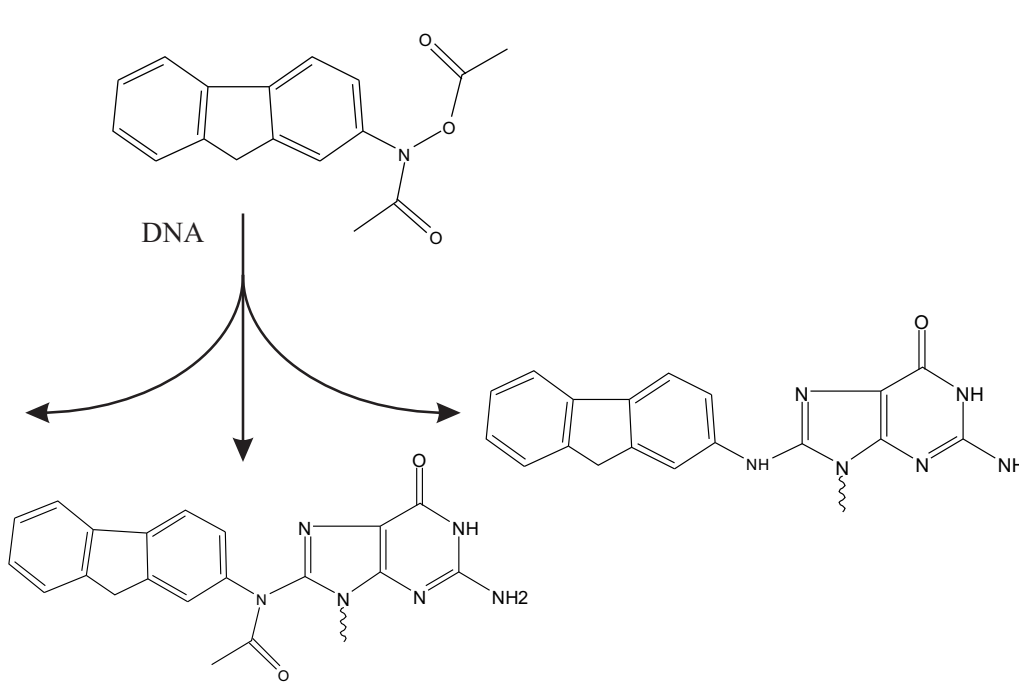

Fig. 3. $a$ - the most common arylamines (left to right): naphthylamine, 4-aminobiphenyl and benzidine; $b$ - interaction of $\mathrm{N}$ acetoxyacetylaminofluorene with DNA leads to bulky adducts formation: 3-(deoxyguanosine-N2-yl)-2acetylaminofluorene (left), N-(deoxyguanosine-8-yl)-2-acetylaminofluorene (middle) or N-(deoxyguanosine-8-yl)-2-aminofluorene (right) tion led to an understanding of the principles of the bulky damages recognizing by the NER system. The impact of the stereochemistry, thermodynamic properties of such DNAs, sequence of damaged DNAs as well as the adduct topology, on the efficiency of lesion recognition and removal from DNA have been considered in a fine details [20-24].

The metabolic transformation of the polycyclic dihydrofuranes of aflatoxin B1 (AFB1), aflatoxin G1 and sterigmatomycin, which are produced by some kinds of fungi, polluting food products, also involves the formation of the corresponding epoxides [25], which interact with DNA.

Another class of compounds, damaging mammalian DNA, is arylamines (Fig. 3). Arylamines are also presented in the tobacco smoke, hair dye and some other sources. Tobacco smoke contains some compounds of the arylamine class, which are known carcinogens, in particular, 2-naphthylamine, 4-aminobiphenyl and benzidine [26] (Fig. 3, a) as well as aminofluorene and acetylaminofluorene. Arylamines may be activated in the process of metabolism in N-hydroxy-, N-acetoxy- or $\mathrm{N}$-sulfoxy compound. Further heterolytic breakage of $\mathrm{N}-\mathrm{O}$ bond leads to the formation of highly active intermediates, forming the extensive adducts during the interaction with DNA [27] (Fig. 3, b). Many works, dedicated to the investigation of the NER mechanism and mutagenesis processes, describe the application of the model DNA, containing N-(deoxyguanosin-8-yl)2-acetylaminofluorene (dGAAF) [28-30]. Another threat to the mammalians is presented by the nitro compounds of the polycyclic aromatic hydrocarbons. These compounds released into the environment from different sources; mainly these are the products of incomplete combustion, but some are also present in food and drinks. 6-nitrochrysene (6-NC) is not the most common compound of this class, but it is also known as a carcinogen, capable to induce breast cancer. The carcinogenic effect of 6-NC exceeds not only that of benzo[a]-pyrene, but also such a powerful carcinogen as heterocyclic aromatic amine 2-amino-1-methyl-6-phenylimidazol[4,5-b]pyrimidine [31]. It is commonly known that the metabolic activation of 6-nitrochrysene may occur in one of two ways (Fig. 4). The first way suggests the ordinary reduction of the nitrogroup with the formation of 6-hydroxylaminochrysene, the interaction of which with deoxyguanosin in DNA leads to the formation of $\mathrm{N}$-(deoxyguanosin-8-yl)-6-aminochrysene and 5-(deoxyguanosin-N(2)-yl)-6-aminochrysene [32, 33]. The second way is the oxidation of the fourth ring of chrysene, the reduction of a nitrogroup with the formation of high-reactive electrophilic intermediate trans-1, 2-dihydroxy-1,2-dihydro-6-hydroxylaminochrysene.The interaction of this intermediate with DNA also leads to 


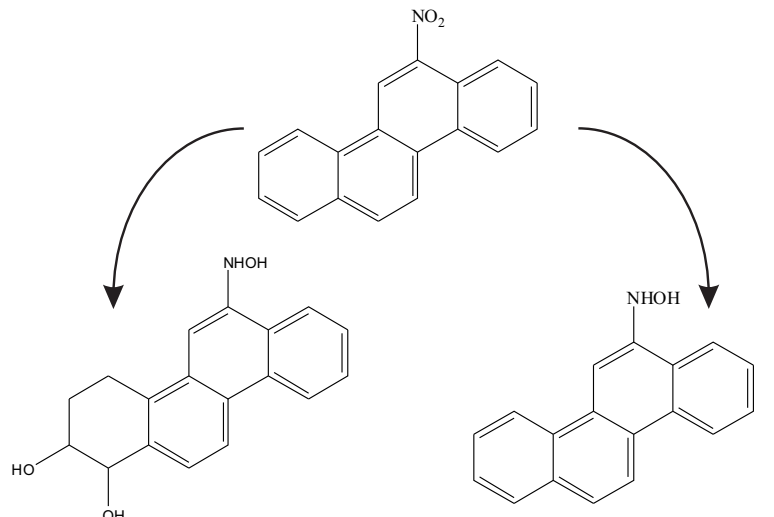

trans-1,2-dihydroxy-1,2 dihydro-6-hydroxylamine chrysene

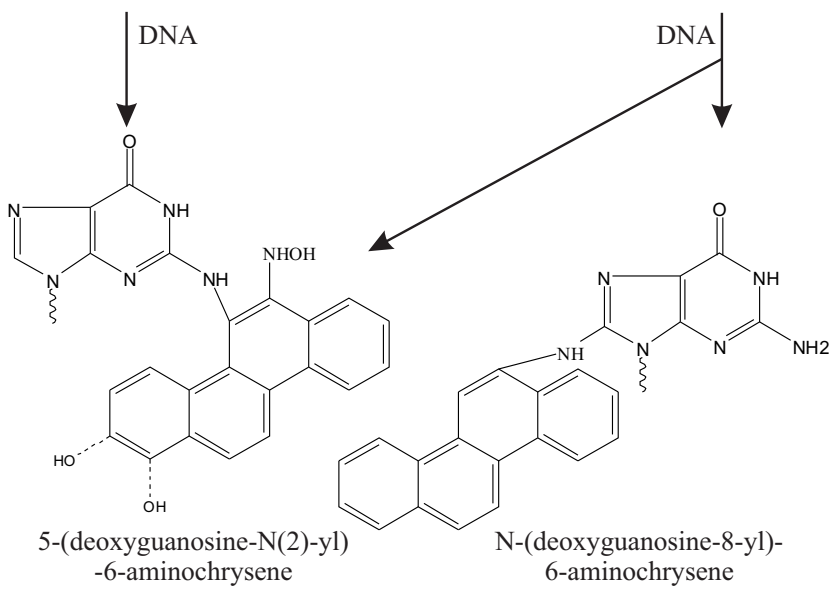

Fig. 4. 6-nitrochrysene activation leads to bulky adducts

the formation of 5-(deoxyguanosin-N(2)-yl)-6-aminochrysene $[34,35]$. It has been recently demon- strated that the repair of these damages occurs with low efficiency (approximately the same with repair of $\mathrm{N}^{2}$-deoxyguanosin-benzo[a]-pyrenyl adducts) [36], i. e. one order less efficiently than the repair of efficient NER substrates - intrastrand crosslinks, introduced into dsDNA due to the effect of platinum derivatives [37, 38].

The effects of the medical preparations on DNA components. Cis-diaminodichloroplatinum (II) (or cisplatin) is one of commonly used chemotherapeutic drug, performing its cytotoxic function via the DNA damaging. Cisplatin is a non-charged complex of bivalent platinum with the configuration of a flat square. Once intravenously injected into the organism, this complex compound remains stable in the blood plasma until it penetrates the cell cytoplasm, where low concentration of chloride ions leads to their replacement in the inner sphere of the complex with water or hydroxy-ions with the formation of the active electrophilic agent. Its interaction with DNA leads to the formation of a monoadduct as well as intrastrand or interstrand crosslinks. Similar to the UV-lesions, the efficiency of repair of the cisplatin-induced damages is affected by the differences in their structure $[39,40]$. An example of the interaction between the pharmacological activity of the substance and its structure is bifunctional platinum anticancer drugs. As stated above, pharmacologically active substances are platinum complexes with the cis-structure $[39,40]$, whereas the trans-isomer (transplatin) has no clinical efficiency. However the complexes with the trans-structure, demonstrating higher cytotoxicity in the tumor cells, have been obtained. The replacement of an amino group in transplatin for an iminoester resulted in a considerable increase in the complex cytotoxicity even in comparison with the cytotoxicity of the corresponding cis-isomer. The trans-( $\mathrm{PtCl}_{2}(\text { E-iminoester })_{2}$ demonstrates high anticancer activity regarding cancer cells, resistant to the effect of commonly used platinum compounds [41]. There have been attempts of elaborating a new generation of antineoplastic preparations, based on platinum II, in order to solve the problem of drug resistance and decreasing the side effects of chemotherapy [42]. The monofunctional complexes of platinum II of the general formula cis- $\left[\mathrm{Pt}\left(\mathrm{NH}_{3}\right)_{2}(\mathrm{~N}\right.$-heterocycle) $\mathrm{Cl}] \mathrm{Cl}$ form a single covalent bond with DNA, introduce minor distortions into the regular structure of dsDNA and differ in their properties from classic reagents like cisplatin. Pyriplatin (a monofunctional complex with pyridine as a ligand) may serve as an example of such drug. The variation of heterocyclic replacements allowed revealing the compounds with high antitumor activity [43]. Phenanthriplatin, containing an extensive ligand phenanthridin (cis- $\left[\mathrm{Pt}\left(\mathrm{NH}_{3}\right)_{2}\right.$ (phenantridin) $\mathrm{Cl}] \mathrm{NO}_{3}$ ), has a considerably higher activity than commonly used cisplatin and oxaliplatin. There are also differences in the spectrum of antitumor activity, demonstrated by this compound, which means that phenanthriplatin may be active regarding the types of cancer cells, demonstrating resistance to common platinum chemotherapy [44].

In recent years the attention of researchers was attracted to bulky adducts, introduced in DNA due to interaction of exocyclic amino groups of DNA purine bases with reactive metabolites of aristolochic acids (MAA). 
<smiles>Cn1cc(CCCNC(=O)CCCCCNC(=O)c2ccc3c(c2)C2(OC3=O)c3ccccc3Oc3ccccc32)c(=O)[nH]c1=O</smiles>

$b$<smiles>Cn1cc(/C=C/CNC(=O)CCNc2nc(F)c(Cl)c([N+]#N)c2F)c(=O)[nH]c1=O</smiles><smiles>COP(=O)([O-])OCC(CNC(=O)CCCCCNC(=O)c1cccc2c1C(=O)OC21c2ccc(O)cc2Oc2cc(O)ccc21)OP(=O)([O-])OC(CNC(=O)CCCCCNC(=O)c1c2ccccc2cc2ccccc12)COP(=O)([O-])OC</smiles>

Fig. 5. Synthetic analogous of damage: $a$ - fluoresceine-5(6)-carboxyaminocaproyl-[5-(3-amino allyl)-2'-deoxyuridine; $b-5-\{\mathrm{N}-[\mathrm{N}-(4-$ azido-2,5-difluoro-3-chloropyridine-6-yl)-3-aminopropionyl]-trans-3aminopropenyl-1\}-2'-deoxyuridine; $c$ - exo-N-[2-N-(N-(4-azido-2,5difluoro-3-chloropyridine-6-yl)-3-aminopropionyl)-aminoethyl]-2'deoxycytidine; $d-$ non-nucleoside fragments of modified DNA strand, containing N-[6-(9-antracenylcarbamoyl)hexanoyl]-3-amino1,2-propandiol; $e$ - non-nucleoside fragments of modified DNA strand, containing N-[6-(5(6)-fluoresceinylcarbamoyl)hexanoyl]-3amino-1,2-propandiol
It has been recently revealed that these components of herbal medical drugs, used for centuries, have serious toxic effect and cause nephropathy, in $50 \%$ leading to cancer [45].

The results of the research, performed using the model DNA, demonstrated that the newly formed MAA derivatives of deoxyguanosine are removed from DNA, whereas the adducts of deoxyadenosine are accumulated in the organism which leads to the progress of diseases [46].

Also has been described the application of the model structures, containing modifications, which introduced into DNA due to the effect of hormonal drugs like premarin. The metabolites of the conjugated estrogens, 4-hydroxyequilenin and 4-hydroxyequilin, are widely used as a components of drugs for the hormone-replacement therapy. They are capable of autoxidation with the formation of $o$-quinones, actively interacting with the nucleobases of DNA, mainly with cytosine, which results in the formation of bulky adducts that are hard to repair [47-49].

The artificial analogues of damages. An example of artificial nucleotide injury is deoxyuridine or deoxythymidine, containing the fluorescein residue, attached to $\mathrm{C} 5$ position via the linker fragment (Fig. 5,a). The monomer moiety for the synthesis of such DNA is a commercially available amidite for the standard solidphase synthesis. It is also possible to introduce this modification using the DNA-polymerase reaction with the modified dNTP as a substrate.

The category of artificial analogues of damages includes recently suggested derivatives of dCMP and dUMP, containing the photoactivated arylazide groups, linked to the nitrogenous bases via extended and flexible linker fragments (Fig. 5, $b, c$ ) [50]. It was demonstrated that such arylazide derivatives of nucleotides introduced into model DNA are recognized as substrates by the bacterial NER system [51] as well as the NER system of the mammalians [52]. The photoactivated analogues of damages expand the capabilities of such research instrument since they allow to perform the study of a multicomponent system NER using the [53]. During repair NER proteins form unstable specific complexes of various compositions and architecture on the damaged DNA. The main idea of affinity modification approach is a covalent fixation of such protein complexes. 
$a$

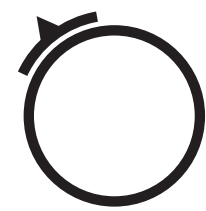

elongation
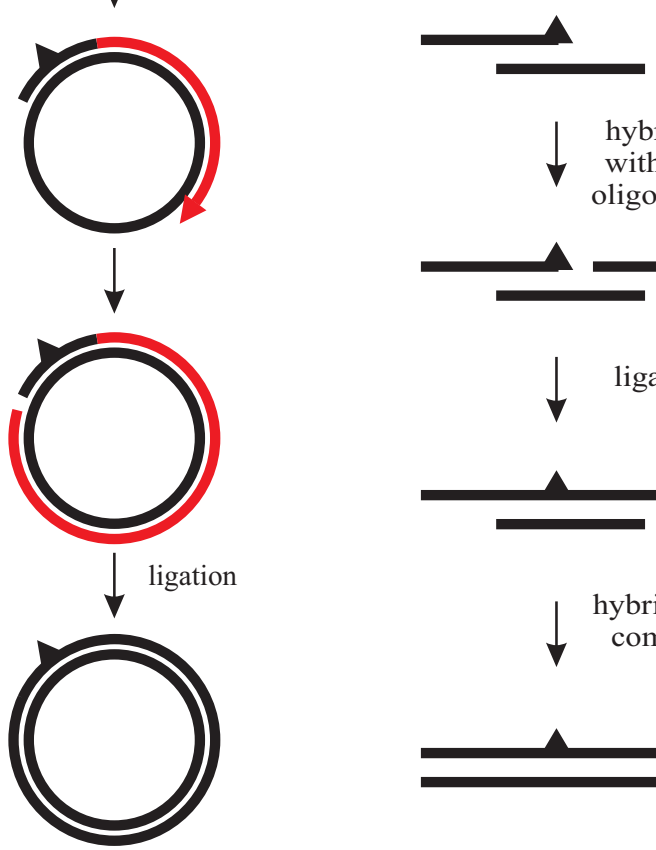

hybridization with flanki oligonucleotide

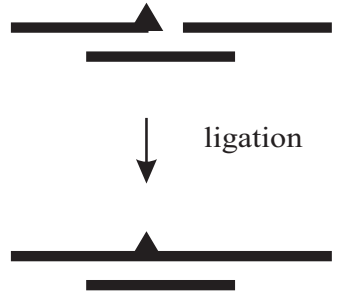

hybridization with $\downarrow$ complementary strand

Recently a novel artificial non-nucleoside damages on the basis of N-[6-(9-antracenylcarbomoyl)hexanoyl]3-amino-1,2-propandiol (nAnt) and N-[6-(5(6)-fluoresceinylcarbomoyl)hexanoyl]-3-amino-1,2-propandiol (nFlu) (Fig. 5, $d, e$ ) have been suggested, which imitate NER-recognizable adducts [54].

The example of the synthetic analogues of the damages to be repaired by NER can be found in the oligopeptide-DNA adducts, the products of proteolytic degradation of larger protein-DNA adducts, formed in the cell under the impact of ionizing radiation, a number of chemical reagents as well as the processes of DNA metabolism [55]. The advantages of artificial damages are the possibility of their introduction into the target position of a DNA molecule and the possibility of variations in their structure, which is often required for the experiments investigating the NER system in vitro.

The model DNA, used to investigate the NER process. In order to form the functionally active preincision NER complex, the damage should either be introduced into a circular DNA [3], or into extended $(\approx 120$ bp) linear duplex [56].
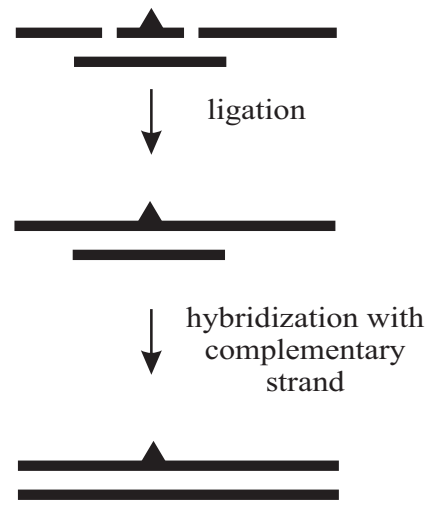

Fig. 6. Model DNA synthesis methods: $a$ - circle DNA; $b$ - synthesis of linear model DNA using enzymatic approach; $c-$ synthesis of linear model DNA using presynthetized oligonucleotides

The circular DNA with multiple damages. A number of works, investigating the substrate properties of a model damages, have been performed using model structures created on the basis of phage or plasmid DNA, which contain damages, statistically distributed along the molecule. The damages are introduced into DNA using either chemical modification or dosed UV-radiation [57]. The subsequent product purification and its analysis allow to estimate the amount and composition of the introduced damages [58]. The characteristics of the obtained model DNA depend on the type of the damaging reagent and the conditions, in which the treatment of the DNA was performed. The context of DNA sequence surrounding the target nucleobase is also important $[59,60]$. The circular DNA, affected by high doses of UV-radiation, was suggested as one of the first model system for the research on the nucleotide excision repair. The irradiation of the plasmid DNA with UV-light at the wavelength of $254 \mathrm{~nm}$ resulted in the formation of both types of photoproducts. The obtained substrate contained the mixture of cyclobutane pyrimidine adducts and 6-4-photoproducts in random positi- 
ons of DNA strands $[58,61]$. There are evident problems and restrictions of such artificial NER substrates use. Nevertheless, such model DNAs was applied to estimate the level of radioactive nucleotides incorporation during the reparative synthesis. This approach was used for investigation of status of NER system [62, 63].

The circular DNA with the damage at the defined position of the strand. The fill-in method based on DNApolymerase-catalyzed reaction is widely used for the synthesis of NER substrates, containing the damage (damages) in the defined position (positions) of the DNA strand. The modified oligonucleotide is used as a primer and the single-stranded form of the circular DNA (plasmid or phage) is used as a template. Then the enzymatic ligation is used to restore the strand integrity (Fig. 6, a) [64, 65]. The method of the modified primer creation is defined by the type of the damage [19, 6668]. This approach to the synthesis of the NER system substrates is rather labor-consuming and does not provide a high yield, but it allows produce modified DNA of certain structure and properties.

The circular DNAs with the damage in the defined position were used to estimate the efficiency of the damages elimination as well as to analyze the NER mechanism [69]. The use of the circular DNA, containing the regions of several uncoupled bases at the distance of 60 bp from the damage at 3'- or 5'-side, allowed confirming the hypothesis of a bipartite mechanism of the damage recognition. It was shown that the efficiency of repair of model DNA, containing the cyclobutane pyrimidine dimers that are hard to repair, increases considerably with the introduction of $3^{\text {nt }}$ bubble at 5 '-side of the damage. The further research, performed with recombinant dimer XPC-HR23B and factor TFIIH - the system of recognition and control of the damage, reconstituted from the purified proteins - demonstrated that connecting to the bubble, XPC promotes the assembly of the protein complex, containing TFIIH. This complex starts to melt the duplex and moves towards the 3'-side from the initial binding place in the search for the damage, containing the bulky chemical modification. During this scanning the complex is translocated along the DNA for the distance, measured with hundreds of base pairs [70].

The linear DNA with the damage at the defined position of the strand. One of the most widely used inst- ruments of in vitro NER investigation are linear dsDNA with the damage at the defined position. Depending on the suggested tasks, these model DNA may be of different length, structure and sequence.

The DNA-duplexes, not exceeding $50 \mathrm{bp}$, were used to study the interaction of specific proteins of the NER system with the damaged DNA by methods of affinity modification, gel-retardation, equilibrium titration as well as immunological techniques. Generally the obtaining of these model DNAs does not cause any complications, especially if the corresponding monomers were available for the automatic standard solid-phase synthesis.

The extended linear DNA-duplexes with the bulky modification in the middle of the strand may be considered as universal models, suitable for the experiments of all the mentioned types [71-74]. Also such DNAs may be used for the investigation of the excision of the damage, as well as the changes of the nucleoprotein complexes, occurring during the NER process, which are associated with each stage $[11,75]$, including the ones in the composition of artificial nucleosomes [76, 77].

These model DNAs may be also obtained via enzymatic ligation of the structure, composed of several short overlapping oligonucleotide fragments. This approach is not complicated and allows varying the type of the damage by replacing the modified oligonucleotide, but the yield of the target extended DNA is not high $5-6 \%$ of the amount of oligonucleotide with the modification [78].

The improved method, providing for considerably higher yield, involves the ligation of the structure, composed of the modified oligonucleotide, which is $12-16$ nucleotides long, and two flanking rather extended (6070 nucleotides) oligonucleotides on the template of the optimal length (30-35 nucleotides). The hybridization of the obtained extended modified DNA and the complementary strand is performed to obtain the target duplex (Fig. 6, c) [54].

Recently the method of creation of NER substrate analogues, involving the use of several enzymes, including DNA-polymerases and DNA-ligase, has also been elaborated (Fig. 6, $b$ ) [79]. A number of modified dNTP, containing photoactive and fluorescent bulky substitutes introduced via long and flexible spacers along the nitrogenous base, were used as substrates of DNApolymerase $[50,80,81]$. Good substrate properties of 
these dNTP and obtained modified oligonucleotides in the reactions, catalyzed by the DNA-polymerase and DNA-ligase, provided a high yield and wide variety of the model DNAs for the NER system investigation [82].

The DNA-analogues of NER substrates as probes for the affinity modification. The method of photoaffinity modification - covalent crosslinking of proteins with DNA-substrate analogues, containing photoactive groups - proved itself as informative approach to the investigation of multicomponent nucleoprotein complexes. The reaction of a covalent attachment may be initiated via UV-irradiation at any suitable time after the formation of a specific non-covalent protein-DNA complex. The activation of photoreagents may be performed in very short time. The adduction may be very efficient in a wide $\mathrm{pH}$ range, ionic strength and the temperature, whereas the reaction conditions often have to be optimized for different types of reactive groups. UVinduced adduction allows analyze even unstable complexes of variable composition. This is especially important for the investigation on the multicomponent dynamic systems of DNA metabolism including the NER system. The variation of the structure of the model DNA allows to investigate interaction between the NER protein factors and the DNA-substrate and their mutual impact as well as the structure and mechanism of functioning of the reparative complexes [51-53, 83]. The DNA probes successfully used to study protein-DNA interaction contain the aryl azide group, introduced as a substitute into the pyrimidine base at $\mathrm{C} 5$ position of $\mathrm{dU}$ (dT) or the exocyclic atom of nitrogen in dC [81]. After UV-radiation the arylazide derivatives generate the shortterm singlet and long-term triplet nitrene, capable to efficiently react with a number of amino acid residues [80, $84,85]$. Being bulky substitutes, these photoreagents distort the structure of the DNA duplex [86], while the halogen- and tio-derivatives such as 5-J-dU and 4S-dU (dT) introduce minimal changes into the DNA structure [87]. Such derivatives do not provide high yield of the covalent adducts, when the source of coherent radiation of high radiation power (laser) was replaced with more common sources of ultraviolet (high pressure mercury lamp, etc.). However, the DNAs containing these derivatives were applied for investigation of NER system [88-91]. In addition, the reaction of $p$-azidophenacylbromide for the inter-nucleotide phosphorothioate may be used to introduce photoactive groups into the DNA-analogues of the NER substrates. The DNAs, containing this modification, were used as photoactive analogues of the undamaged chain [51]. The variation of the type of reagents and damages and their mutual location provides possibilities to design the efficient probes for the NER the mechanism investigation using the affinity modification method.

The experiments using the photoactive model DNA resulted in a considerable advancement in the understanding of the mechanism of key stages of the NER eukaryotic system - damage recognition and preincision complex formation. The pyrimidine nucleoside-5'-triphosphates containing bulky fluorochloroazidobenzoyl (Fab) and fluorochloroazidopyridyl (Fap) groups have good substrate properties in the DNA-polymerase reaction and the efficiency as photoreagents. That allowed to synthesize the set of DNA-probes with photoreactive damages [50].

The analysis of the interaction of human recombinant RPA and XPA with the modified DNA-duplexes of different structure as well as single-stranded DNA, containing Fab-dUMP (5-\{[4-(4-azido-2,3,5,6-tetrafluorobenzoylamino) butyl]-aminocarbonyl-carbamoyl-propyl-oxymethyl $\}$-2'-deoxyuridine-5'-monophosphate) or fluorochloroazidopyridyl modifications Fap-dUMP (5$\{\mathrm{N}-[\mathrm{N}-(4-a z i d o-2,5-d i f l u o r o-3-c h l o r o p y r i d y l-6-y l)-3-$ aminopropionyl]-trans-3-aminopropenyl-1 $\}$-2'-deoxyuridine-5'-monophosphate) or Fap-dCMP (exo-N- $\{2-$ [N-(4-azido-2,5-difluoro-3-chlorpyridine-6-yl)-3-aminopropionyl]-aminoethyl\}-2'-deoxycytidinine-5'-monophosphate), demonstrated that the efficiency of photoaffinity labeling depends on the structure of both DNA and the photoanalogue. The presence of extended single-stranded fragments in the DNA-probe played a crucial role in the interaction with RPA. The exception was effective RPA-DNA adducts formation when the probe represents DNA duplex containing nick flanked by FabdNMP on 5'-side.

This was likely to be related to the substantial structural distortion in the DNA, induced by bulky modification at the 5'-end of the oligonucleotide, bearing high flexibility in the undamaged strand. XPA did not demonstrate preference to single-stranded or double-stranded DNA, and was interacted more efficiently with DNAduplexes containing nick [12]. 
The interaction of XPC-HR23B, RPA and XPA with the DNA-duplexes, containing the photoactive damages Fap-dC and Fap-dU in the inner positions, was also studied. Fap-dC in the context of $3^{\text {nt }}$ mismatch interacted with XPC more efficiently. This is in agreement with a higher level of specific excision of the damaged fragment from the corresponding plasmid DNA. The level of the photocrosslinking as well as the level of specific excision for Fap-dU did not depend considerably on the complementarity of the pair, containing the damage [52].

To analyze NER factors capability to contact with the damaged and undamaged strands of the substrate, the set of DNA probes of different structure have been used. Photoactive strand of the ds DNA contained damageimitating Fap-dNMP or not distorting 4-S-dUMP. The second DNA strand either did not contain any modifications, or contained a bulky modified nucleotide (AntrdCMP) opposite the photoactive group. During the photocrosslinking of XPC-HR23B the covalent adducts with 48-bp-DNA probe were formed only by the XPC-subunit of the heterodimer. The XPC modification level was increased by the RPA presence. The amount of photocrosslinked XPC was below the detection level while using the DNA with in oppositely located bulky modifications in both strands. This indicated that the binding of XPC required the intact complementary strand opposite the damage. The direct evidence of the role of the undamaged DNA strand in this interaction was later obtained using the X-ray structural analysis of the yeast ortholog of XPC complex and other experiments $[92,93]$. The introduction of bulky modification into the second strand decreased the level of RPA modification considerably, which is also explained by preferential coupling of the undamaged chain that is the function, performed by RPA in the NER process $[94,95]$. The presence of the second damage did not impact the XPA modification considerably. Therefore, the data, obtained due to the experiments of the photocrosslinking of RPA and XPA, indicates that the XPA factor prefer the damaged chain, and the RPA factor - the undamaged chain [96].

The equilibrium fluorescent titration was used to estimate the parameters of the affinity of RPA to the series of DNA-duplexes, containing bulky substitutes, introduced into the pyrimidine bases. Since this protein has twice higher affinity to the single-stranded DNA than to double-stranded DNA, it was assumed that in this case
RPA may serve as a specific sensor of a single-strand character in the DNA-duplexes, caused by the distortion of the DNA structure via the introduction of bulky substitutes. It was demonstrated that the affinity of the modified DNA exceeds 3-20-fold the affinity of this protein to the DNA-duplex, not containing any modifications. Using 5-J-dU-containing duplexes it was demonstrated that the level of RPA modification decreased rapidly when an bulky substitute introdused in the complementary chain opposite photoactive nucleotide [79].

The stimulating effect of RPA on the formation of XPC-HR23B complexes with DNA was observed in the analysis of the interaction of proteins XPC-HR23B, XPA and RPA with the duplexes, containing the photoreactive residue 5-J-dUMP in one of the strands, and fluorescein-replaced derivative of dUMP as the damage in the second one. The synergism in the interaction of proteins XPA and XPC-HR23B with DNA was observed in case of their simultaneous presence in the reaction mixture. The amount of modification products of proteins XPA, RPA and XPC was depended on the mutual location of the damage and the photoactivated group and correlated with the affinity of these proteins to the damaged DNA, estimated by the gel retardation [91]. The detailed analysis of the interaction of XPA and RPA with the damaged and undamaged DNA strands was performed using a series of photoactive J-dU-DNA with different mutual location of the photoreagent and a damaged nucleotide, which contains a fluorescein residue [90]. For this experiments the model DNA mimicking the repair intermediate (a DNA-duplex containing an noncomplementary fragment of 15 nucleotides), were used. The application of the photocross-linking methods, gel retardation and enzymatic footprinting allowed determining the site of the damaged DNA, with which these proteins contact more intensively. It was confirmed that XPA and RPA mutually stimulate their binding to DNA. It was also confirmed that RPA mainly interacts with the undamaged DNA strand that supported the conclusion that XPA has contacts with the damaged chain, located at the 5'-side of the damage. The asymmetry regarding the damaged and undamaged chains and the synergism in the interaction of XPA and RPA with the damaged DNA was also observed in some previous works. The cisplatin-induced intrastrand linking of DNA and cholesterol modifications were used 
as damages in these works, while $\mathrm{J}$ - and Br-dUMP as well as J-dCMP were used as photoreagents [14, 88].

The photoaffinity labeling together with the estimation of the affinity to the DNA-substrate by the gel retardation and the equilibrium titration allowed comparing the properties of human recombinant XPC-HR23B and yeast $\operatorname{Rad} 4 / \operatorname{Rad} 23$ [93]. The comparative analysis of the interaction of two eukaryotic sensors with bulky damages and a set of model DNA-duplexes, containing a fluorescein residue and 5-J-dUMP as a photoactive link in different positions of the chain revealed crucial similarity in their interaction with the damaged DNA and some differences in the details of this interaction. The data on the contacts of these proteins with the DNA containing bulky lesion, supports model, created previously on the basis of the results of the X-ray structural analysis. In this analysis the crystals of the triple complex containing $\operatorname{Rad} 23$, the truncated form of $\operatorname{Rad} 4$ and the DNAduplex containing the UV-damage was used [92].

As for the duplexes, containing both Fap-dC and the platinum adduct in one chain [82], regardless of the mutual location of these bulky modifications in the DNA molecule, the target of the modification was only a large subunit of XPC-HR23B complex. The second adduct with lower electrophoretic mobility is the most likely product of photocrosslinking of the DNA-binding subunit of XPC along other amino acid residues [89]. The products of labeling of the $58 \mathrm{kDa}$ regulatory subunit HR23B were not detected in any reaction mixtures after the photocrosslinking. In addition, the product of cross-linking between XPC and HR23B subunits, revealed using the Western-blotting, was not have radioactive label and is formed regardless of the presence of the DNA-probe [82]. The absence of the products of photocross-linking of HR23B to the analogues of the damaged DNA indicated that this subunit of the complex does not participate in any direct contacts with DNA. One might assume that the absence of the modification products for a small subunit was conditioned by the topology of the heterodimer coupling with DNA, steric complications, caused by the location of subunits. However, it has been recently shown in the experiments in vivo that a small subunit is released from the complex while XPC binds to the damage [97].

To investigate the order of NER factors binding to the DNA-substrate, the model DNA, containing the 1,3- intrastrand link $\mathrm{G}^{*} \mathrm{CG}^{*}$, obtained in the reaction with cis-diaminodichloroplatinum was used. It should be noted that the structure of this model DNA is characterized in details. For instance, it is known that the axis of dsDNA strand, containing 1,3-Pt-modification, forms an approximate $150^{\circ}$ angle, and the complementary interactions of bases from the position «-3» (relative to the damage) to the position «+3» were distorted [98100]. The photoaffinity modification experiments were performed using DNA, containing the photoactive 5(N-p-azidobenzoyl)-3-aminoallyl)-dUMP (Az-dUMP) in with such a Pt-damage in the same strand. The data, obtained in the permanganate foot-printing in the presence of recombinant XPC-HR23B, RPA, XPA, XPF, $\mathrm{XPG}$ and TFIIH (in different combinations), together with the data of photocrosslinking allow to detect the conformational changes in the damaged DNA. These changes were induced by the binding of NER factors and led to the formation of an asymmetric bubble around the damage from the position «-20» to «+9». The order of binding and positioning of these proteins was suggested. However Az-dUMP can also introduce some distortions in the dsDNA structure, the modification patterns actually reflect the interaction of the NER factors and DNA, containing two damages, so the interpretation of the photocross-linking results becomes complicated.

The research, performed with the set of photoactive model DNA, also provided insight into the mechanism of functioning of the prokaryotic system NER (UvrABC). One of the key stages of the work of the NER prokaryotic system, the mechanism of which has not been determined for a long time, is the transfer of the damaged DNA from UcrA to UvrB, preceding the UvrC-catalyzed incision. Two types of arylazide photoaffinity reagents were used to determine this mechanism. The role of the damage in the first type of probes was played by the fluorescein residue, introduced as a substituent via a linker on deoxytimidine. In this case $p$-azidophenacyl derivative of deoxyoligonucleotide was used as a photoactive analogue of the undamaged chain. Other probes contained photoactive damages Fabc-dUMP or FabdCMP, modified nucleotides, where a fluoroarylobenzoyl group was introduced via linkers on nitrogenous bases. The application of photoactive DNA-analogues of substrates revealed the principles of damage recog- 
nizion and the details of interaction between factors UvrA, UrvB and UrvC and DNA in the NER process. It was demonstrated that the «transfer» of the damaged DNA from UvrA to UvrB consists of three stages. At the first stage UvrA and UvrB are linked to the place of the damage, and the direct contact with the damage is performed by UvrA. At the second stage there is a reaction of relocation of the damage containing fragment of DNA strand with the ATP consumption, where UvrB mainly contacts with the undamaged DNA, and at the third stage a special pocket-like structure of UvrB binds to the damage with the simultaneous release of UvrA. Then the complex ready for the excision is formed with the introduction of UvrC into this complex [51].

The photoaffinity modification technique was applied to search for mammalian cells NER-competent extracts proteins, specifically interacting with bulky substituted DNA. The proteins of HeLa cell extract selectively and efficiently interacted with Fap-dC- and FapdU-duplexes (48 bp). The major targets of the modification were several proteins with apparent molecular weight of 35-90 kDa. The application of specific antibodies allowed to identify a large RPA subunit (p70) as modification target [89]. The experiments with the purified recombinant protein also demonstrated that RPA efficiently crosslinked with dsDNA, containing bulky damages. The major role in the interaction with damaged DNA was played by $p 70$ [79]. Using the more extended DNA probe (137 bp Fap-dC-DNA) the relationship of modification and the ratio of the concentrations of DNA and protein extract was demonstrated. Decrease of the concentration of extract proteins was led to the broadening of the set of the targets forming covalent adducts to DNA.

The most probable reason of the observed effect was the increase in the possibility for proteins with the higher affinity to the damaged DNA to compete for the photoactive group with the abundant protein of cancer cell extracts $-\mathrm{Ku} 70 / 80$ antigen [101]. This assumption was confirmed by the differences in the patterns of the protein modification of the NER-competent extracts of HeLa and the Chinese hamster ovarian cells (CHO). The application of the functional test, based on the use of $\mathrm{NAD}^{+}$, allowed identifying the $115-\mathrm{kDa}$ protein of the $\mathrm{CHO}$ extract, forming the adducts with the extended DNA-probe, as PARP1 [102].
The experiments with dsDNA probes of different length, containing photoactivated (benzophenone) derivatives of cisplantin allowed performing the massspectrometry identification of a number of proteins of the mammalian cell extracts, interacting with the bulky damage. It should be noted that there are differences in the modification patterns, determined using the probes of different length, containing similar modification. The main targets of photocrosslinking for 1,3 Pt(GCG)DNA probe were $\mathrm{Ku} 70 / \mathrm{Ku} 80$, DNA-dependent proteinkinase, DNA-ligase III, PARP1 and RPA (p70) [73].

The model DNA and the estimation of the excision activity of the NER system. The recognition and excision of damage is a key stage of NER. The accurate and reliable evaluation of the specific excision activity is required both for medical and fundamental research. It would be useful for the investigation of the mechanisms of bulky damage repair in reconstituted systems. Also the estimation of the NER system activity in the tumor cells would be useful to select appropriate chemotherapeutic drugs. It would probably help to correct the method of anticancer treatment during therapy. Not very sophisticated and convenient method of NER system functional status control has not yet developed. One of the important conditions for the development of this method is the existence of easily accessible and effective substrate of excision. The long linear dsDNA appears most promising for the elaboration of a NER activity test system, despite some of the problems associated with their use in the real systems like extracts of tissues and cells [101, 103, 104]. The linear DNA substrates are more available, especially if for their preparation can be used the standard automatic solid-phase synthesis.

The second important characteristic is good substrate properties of the model damage, high efficiency of its conversion. For instance, the occurrence of the products of the excision reaction was not registered for the linear DNA duplex of $120 \mathrm{bp}$, containing the acetylaminofluorene modification (AAF-dG). A well-detectable level of excision of the AAF-dG-containing fragment was observed only for the circular substrate [27].

The model DNA, containing nAnt and nFlu have been suggested as a substrates of NER system. The modified deoxyoligonucleotides were synthesized using the standard solid-phase synthesis and the corresponding 
non-nucleosidic phosphoramidites. The nFlu and nAnt containing extended (137 bp) linear DNA-duplexes demonstrated the properties of efficient substrates of specific excision reaction, catalyzed by the proteins of the NER-competent extracts of eukaryotic cells. It has been shown that incubation of these DNA with extracts of $\mathrm{CHO}$ cells as well as the extracts, obtained from HeLa, $\mathrm{SiHa}$ and $\mathrm{C} 33 \mathrm{~A}$ cells results in the formation of the fragments of specific sequence and size. The levels of a relative activity of specific endonucleases of the extracts differed 1.5-2-fold, and the excision profiles matched for all the extracts. Therefore, the use of nFlu- and nAntDNA allows estimating the level of the activity of the NER system in the extracts of cells of different origin. The radioactive labeling of the reaction products was performed using the DNA-polymerase and $\alpha-{ }^{32} \mathrm{P}-\mathrm{dCTP}$. The template for fill-in synthesis was complementary to the DNA fragment which contains the damage [105]. The 5'-end of the template contains the oligo-dG-fragment; the 3'-end is protected from elongation with phosphorylation. This approach allows using the non-radioactive model DNA. At the same time the sensitivity of the method is considerably increased and one can reveal the products of the specific hydrolysis even at low excision levels.

Using the model DNA, containing the radioactive label $\left({ }^{32} \mathrm{P}\right)$ near the damage, it is possible to perform the direct detection of the excision products [64]. The advantages of this method are the absence of the additional stages and the possibility of a quantitative estimation of the excision efficiency. Considerable disadvantages of this method should be also noted. Firstly, the applied model DNA should have high relative radioactivity which requires additional special protection during the synthesis and storage of these compounds. Secondly, such highly radioactive molecules have an extremely short lifetime which limits their application in the series of experiments.

Conclusions. Using various methods including the target mutagenesis, X-ray structural research as well as fluorescent microscopy in the living cell, the considerable progress have been done in the NER process investigation. The biochemical approaches based on the application of the model DNA though remain very applicable to get insight of NER proteins interaction with DNA-substrate and their mutual interactions in the spe- cific nucleoprotein complexes $[72,106,107]$. The actuality of these investigations is also supported by the broadening of the spectrum of the genotoxic factors. In addition, the majority of antitumor agents, used in the clinical practice, also realize their cytotoxicity via damaging DNA. However due to a wide substrate specificity of NER, this repair system action interfere with the safety of the damages, thus the medicinal effect of the drugs is decreased.

Therefore, the understanding of the mechanisms of functioning of protein complexes and the possibility of estimation of the functional status of the NER system using the model DNA are required for successful design of drugs for the anticancer chemotherapy.

Funding. The work was supported by the Russian Foundation for Fundamental Research (Grant 12-0400487a), the Russian Academy of Sciences (the programs of fundamental research in the field of molecular and cell biology), the Ministry of Education and Science of the Russian Federation (NSh-420.2014.4) and COMFI 13-04-40197.

Модельные ДНК для исследования механизма нуклеотидной эксцизионной репарации

А. Н. Евдокимов, О. И. Лаврик, И. О. Петрусева

Резюме

ДНК живых клеток находится под постоянным воздействием различных повреждающих факторов экзо- и эндогенного происхождения. Нуклеотидная эксиизионная репараиия (NER) удаляет из ДНК широкий набор объемных аддуктов, образовавшихся в результате воздействия УФ облучения, а также электрофильных веществ - загрязнителей окружающей среды, оказывающих мутагенное действие, и химиопрепаратов. В прочессе репарачии, проводимой системой NER млекопитающих, происходит специфическое выщепление из ДНК фрагментов размером 24-32 нуклеотида, содержащих повреждения. Последуюший репаративный синтез и лигирование ДНК восстанавливают интактность спирали ДНК. Идентифицированы гены, инактивированные в NERдефицитных клетках выстих эукариотов. В репарации участвуют примерно 30 белков, формирующих специфические многосубъединичные комплексы. Система NER характеризуется широкой субстратной специфичностью и при этом большими различиями в эффективности удаления повреждений. Ключевой лимитирующей стадией проиесса является узнавание и верификаиия повреждения. К эффективным и развиваюшимся подходам к исследованию процесса NER принадлежит метод, основанный на использовании модельных ДНК - синтетических структур, являющихся аналогами субстрата или интермедиатов этого процесса. Рассмотрены существуюшие данные о способах конструирования модельных ДНК и применении их в качестве инструмента для всестороннего изучения прочесса NER.

Ключевые слова: нуклеотидная эксиизионная репараџия, объемные ДНК-аддукты, модельные ДНК. 
Модельні ДНК для дослідження механизму нуклеотидної ексцизійної репарації

\section{А. Н. Євдокимов, О. І. Лаврик, І. О. Петрусева}

\section{Резюме}

ДНК живих клітин перебуває під постійним впливом різноманітних пошкоджуючих факторів екзо- $і$ ендогенного походження. Нуклеотидна ексиизійна репарація (NER) видаляє з ДНК широкий набір об 'ємних адуктів, які утворилися в результаті дії УФ опромінення, а також електрофільних речовин-забруднювачів довкілля, щчо чинять мутагенний вплив, та хіміопрепаратів. $У$ процесі репарації, яку виконує система NER ссавиів, відбувається специфічне вищеплювання з ДНК фрагментів розміром 24-32 нуклеотиди, що містять пошкодження. Подальший репаративний синтез і лігування ДНК відновлюють інтактність спіралі ДНК. Iдентифіковано гени, інактивовані в NER-дефіцитних клітинах вищих евкаріотів. В репарації беруть участь приблизно 30 білків, які формують специфічні мультисубодиничні комплекси. Система NER характеризується широкою субстратною специфичністю і при иуьому великими розбіжностями в ефективності видалення пошкоджень. Ключовою лімітуючою стадією прочесу є упізнавання та верифікація пошкоджен. До ефективних і таких, щз розвиваються, підходів до вивчення прочесу NER належить метод, заснований на використанні модельних ДНК - синтетичних структур, які є аналогами субстрата або інтермедіатів ијього прочесу. Розглянуто існуючі дані щзодо способів конструювання модельних ДНК та застосування їх як інструмента для всебічного дослідження прочесу NER.

Ключові слова: нуклеотидна ексиизійна репарація, об'ємні ДНК-адукти, модельні ДНК.

\section{REFERENCES}

1. Dip R, Camenisch U, Naegeli H. Mechanisms of DNA damage recognition and strand discrimination in human nucleotide excision repair. DNA Repair (Amst). 2004; 3(11):1409-23.

2. Scharer $O D$. Chemistry and biology of DNA repair. Angew Chem Int Ed Engl. 2003; 42(26):2946-74.

3. Gillet LC, Scharer OD. Molecular mechanisms of mammalian global genome nucleotide excision repair. Chem Rev. 2006; 106 (2):253-76

4. Lehmann AR. DNA repair-deficient diseases, xeroderma pigmentosum, Cockayne syndrome and trichothiodystrophy. Biochimie. 2003; 85(11):1101-11.

5. Hanawalt PC, Spivak G. Transcription-coupled DNA repair: two decades of progress and surprises. Nat Rev Mol Cell Biol. 2008; 9(12):958-70.

6. Mellon I, Spivak G, Hanawalt PC. Selective removal of transcription-blocking DNA damage from the transcribed strand of the mammalian DHFR gene. Cell. 1987; 51(2):241-9.

7. Scharer $O D$. Nucleotide excision repair in eukaryotes. Cold Spring Harb Perspect Biol. 2003; 5(10):a012609.

8. Friedberg EC. How nucleotide excision repair protects against cancer. Nat Rev Cancer. 2001; 1(1):22-33.

9. Sugasawa K, Okamoto T, Shimizu Y, Masutani C, Iwai S, Hanao$k a F$. A multistep damage recognition mechanism for global genomic nucleotide excision repair. Genes Dev. 2001; 15(5):507-21.

10. Kusumoto R, Masutani C, Sugasawa K, Iwai S, Araki M, Uchida $A$, Mizukoshi $T$, Hanaoka $F$. Diversity of the damage recognition step in the global genomic nucleotide excision repair in vitro. Mutat Res. 2001; 485(3):219-27.
11. Geacintov NE, Broyde S, Buterin T, Naegeli H, Wu M, Yan S, Patel $D J$. Thermodynamic and structural factors in the removal of bulky DNA adducts by the nucleotide excision repair machinery. Biopolymers. 2002; 65(3):202-10.

12. Maltseva EA, Rechkunova NI, Petruseva IO, Silnikov VN, Vermeulen $W$, Lavrik OI. Interaction of nucleotide excision repair factors RPA and XPA with DNA containing bulky photoreactive groups imitating damages. Biochemistry (Mosc). 2006; 71 (3):270-8

13. Tapias A, Auriol J, Forget D, Enzlin JH, Scharer OD, Coin F, Coulombe B, Egly JM. Ordered conformational changes in damaged DNA induced by nucleotide excision repair factors. $J$ Biol Chem. 2004; 279(18):19074-83.

14. Hermanson-Miller IL, Turchi JJ. Strand-specific binding of RPA and XPA to damaged duplex DNA. Biochemistry. 2002; 41 (7): 2402-8.

15. Sancar A. Structure and function of DNA photolyase and cryptochrome blue-light photoreceptors. Chem Rev. 2003; 103(6): 2203-37.

16. Reardon JT, Sancar A. Recognition and repair of the cyclobutane thymine dimer, a major cause of skin cancers, by the human excision nuclease. Genes Dev. 2003; 17(20):2539-51.

17. Mitchell $D L$. The relative cytotoxicity of (6-4) photoproducts and cyclobutane dimers in mammalian cells. Photochem Photobiol. 1988; 48(1):51-7.

18. Smith CA, Taylor JS. Preparation and characterization of a set of deoxyoligonucleotide 49-mers containing site-specific cis-syn, trans-syn-I, (6-4), and Dewar photoproducts of thymidylyl (3' $\rightarrow$ 5')-thymidine. J Biol Chem. 1993; 268(15):11143-51.

19. Szymkowski DE, Lawrence $C W$, Wood RD. Repair by human cell extracts of single (6-4) and cyclobutane thymine-thymine photoproducts in DNA. Proc Natl Acad Sci USA. 1993; 90(21): 9823-7.

20. Mocquet V, Kropachev K, Kolbanovskiy M, Kolbanovskiy A, Tapias A, Cai Y, Broyde S, Geacintov NE, Egly JM. The human DNA repair factor XPC-HR23B distinguishes stereoisomeric benzo[a]pyrenyl-DNA lesions. EMBO J. 2007; 26(12):2923-32.

21. Reeves DA, Mu H, Kropachev K, Cai Y, Ding S, Kolbanovskiy A, Kolbanovskiy M, Chen Y, Krzeminski J, Amin S, Patel DJ, Broyde $S$, Geacintov NE. Resistance of bulky DNA lesions to nucleotide excision repair can result from extensive aromatic lesionbase stacking interactions. Nucleic Acids Res. 2011; 39(20): 8752-64.

22. Kropachev K, Kolbanovskii M, Cai Y, Rodriguez F, Kolbanovskii A, Liu Y, Zhang L, Amin S, Patel D, Broyde S, Geacintov NE. The sequence dependence of human nucleotide excision repair efficiencies of benzo[a]pyrene-derived DNA lesions: insights into the structural factors that favor dual incisions. $J$ Mol Biol. 2009; 386(5): 1193-203.

23. Cai Y, Geacintov NE, Broyde S. Nucleotide excision repair efficiencies of bulky carcinogen-DNA adducts are governed by a balance between stabilizing and destabilizing interactions. Biochemistry. 2012; 51(7):1486-99.

24. Kropachev K, Kolbanovskiy M, Liu Z, Cai Y, Zhang L, Schwaid AG, Kolbanovskiy A, Ding S, Amin S, Broyde S, Geacintov NE. Adenine-DNA adducts derived from the highly tumorigenic Dibenzo[a,1]pyrene are resistant to nucleotide excision repair while guanine adducts are not. Chem Res Toxicol. 2013; 26(5): 783-93.

25. Baertschi SW, Raney KD, Shimada T, Harris TM, Guengerich FP. Comparison of rates of enzymatic oxidation of aflatoxin B1, aflatoxin $\mathrm{G} 1$, and sterigmatocystin and activities of the epoxides in forming guanyl-N7 adducts and inducing different genetic responses. Chem Res Toxicol. 1989; 2(2):114-2. 
26. Gan J, Skipper PL, Gago-Dominguez M, Arakawa K, Ross RK, $Y u M C$, Tannenbaum SR. Alkylaniline-hemoglobin adducts and risk of non-smoking-related bladder cancer. J Natl Cancer Inst. 2004; 96(19):1425-31.

27. Gillet LC, Alzeer J, Scharer OD. Site-specific incorporation of $\mathrm{N}$-(deoxyguanosin-8-yl)-2-acetylaminofluorene (dG-AAF) into oligonucleotides using modified «ultra-mild» DNA synthesis. Nucleic Acids Res. 2005; 33(6):1961-9.

28. Johnson DL, Reid TM, Lee MS, King CM, Romano LJ. Preparation and characterization of a viral DNA molecule containing a site-specific 2-aminofluorene adduct: a new probe for mutagenesis by carcinogens. Biochemistry. 1986; 25(2):449-56.

29. O'Handley SF, Sanford DG, Xu R, Lester CC, Hingerty BE, Broyde S, Krugh TR. Structural characterization of an N-acetyl2-aminofluorene (AAF) modified DNA oligomer by NMR, energy minimization, and molecular dynamics. Biochemistry. 1993; 32(10):2481-97.

30. Alzeer J, Scharer OD. A modified thymine for the synthesis of site-specific thymine-guanine DNA interstrand crosslinks. Nucleic Acids Res. 2006; 34(16):4458-66.

31. el-Bayoumy K, Chae YH, Upadhyaya P, Rivenson A, Kurtze C, Reddy B, Hecht SS. Comparative tumorigenicity of benzo[a]pyrene, 1-nitropyrene and 2-amino-1-methyl-6-phenylimidazo[4, 5 -b]pyridine administered by gavage to female $\mathrm{CD}$ rats. Carcinogenesis. 1995; 16(2):431-4.

32. Delclos KB, Miller DW, Lay JO, Jr., Casciano DA, Walker RP, $F u$ PP, Kadlubar FF. Identification of C8-modified deoxyinosine and N2- and C8-modified deoxyguanosine as major products of the in vitro reaction of N-hydroxy-6-aminochrysene with DNA and the formation of these adducts in isolated rat hepatocytes treated with 6-nitrochrysene and 6-aminochrysene. Carcinogenesis. 1987; 8(11):1703-9.

33. Chae YH, Delclos KB, Blaydes B, el-Bayoumy K. Metabolism and DNA binding of the environmental colon carcinogen 6-nitrochrysene in rats. Cancer Res. 1996; 56(9):2052-8.

34. Brooks PJ, Wise DS, Berry DA, Kosmoski JV, Smerdon MJ, Somers RL, Mackie H, Spoonde AY, Ackerman EJ, Coleman K, Tarone $R E$, Robbins $J H$. The oxidative DNA lesion 8,5'-(S)cyclo-2'-deoxyadenosine is repaired by the nucleotide excision repair pathway and blocks gene expression in mammalian cells. $J$ Biol Chem. 2000; 275(29):22355-62.

35. El-Bayoumy K, Sharma AK, Lin JM, Krzeminski J, Boyiri T, King $L C$, Lambert G, Padgett $W$, Nesnow $S$, Amin $S$. Identification of 5-(deoxyguanosin-N2-yl)-1,2-dihydroxy-1,2-dihydro-6-amino chrysene as the major DNA lesion in the mammary gland of rats treated with the environmental pollutant 6-nitrochrysene. Chem Res Toxicol. 2004; 17(12):1591-9.

36. Krzeminski J, Kropachev K, Kolbanovskiy M, Reeves D, Kolbanovskiy A, Yun BH, Geacintov NE, Amin S, El-Bayoumy K. Inefficient nucleotide excision repair in human cell extracts of the $\mathrm{N}$-(deoxyguanosin-8-yl)-6-aminochrysene and 5-(deoxyguano$\sin -\mathrm{N}(2)$-yl)-6-aminochrysene adducts derived from 6-nitrochrysene. Chem Res Toxicol. 2011; 24(1):65-72.

37. Zamble DB, Mu D, Reardon JT, Sancar A, Lippard SJ. Repair of cisplatin-DNA adducts by the mammalian excision nuclease. Biochemistry. 1996; 35(31):10004-13.

38. De Silva IU, McHugh PJ, Clingen PH, Hartley JA. Defining the roles of nucleotide excision repair and recombination in the repair of DNA interstrand cross-links in mammalian cells. Mol Cell Biol. 2000; 20(21):7980-90.

39. Johnson NP, Macquet JP, Wiebers JL, Monsarrat B. Structures of the adducts formed between [ $\mathrm{Pt}(\mathrm{dien}) \mathrm{Cl}] \mathrm{Cl}$ and DNA in vitro. Nucleic Acids Res. 1982; 10(17):5255-71.
40. Jamieson ER, Lippard SJ. Structure, recognition, and processing of cisplatin-DNA adducts. Chem Rev. 1999; 99(9):2467-98.

41. Kasparkova J, Novakova O, Farrell N, Brabec V. DNA binding by antitumor trans-[PtCl2(NH3)(thiazole)]. Protein recognition and nucleotide excision repair of monofunctional adducts. Biochemistry. 2003; 42(3):792-800.

42. Wang D, Zhu G, Huang X, Lippard SJ. X-ray structure and mechanism of RNA polymerase II stalled at an antineoplastic monofunctional platinum-DNA adduct. Proc Natl Acad Sci USA. 2010; 107(21):9584-9.

43. Zhu G, Myint M, Ang WH, Song L, Lippard SJ. Monofunctional platinum-DNA adducts are strong inhibitors of transcription and substrates for nucleotide excision repair in live mammalian cells. Cancer Res. 2012; 72(3):790-800.

44. Park GY, Wilson JJ, Song Y, Lippard SJ. Phenanthriplatin, a monofunctional DNA-binding platinum anticancer drug candidate with unusual potency and cellular activity profile. Proc Natl Acad Sci USA. 2012; 109(30):11987-92.

45. Chen CH, Dickman KG, Moriya M, Zavadil J, Sidorenko VS, Edwards KL, Gnatenko DV, Wu L, Turesky RJ, Wu XR, Pu YS, Grollman AP. Aristolochic acid-associated urothelial cancer in Taiwan. Proc Natl Acad Sci USA. 2012; 109(21):8241-6.

46. Grollman AP, Shibutani S, Moriya M, Miller F, Wu L, Moll $U$, Suzuki N, Fernandes A, Rosenquist T, Medverec Z, Jakovina K, Brdar B, Slade N, Turesky RJ, Goodenough AK, Rieger R, Vukelic $M$, Jelakovic $B$. Aristolochic acid and the etiology of endemic (Balkan) nephropathy. Proc Natl Acad Sci USA. 2007; 104(29): 12129-34.

47. Zhang F, Chen $Y$, Pisha E, Shen L, Xiong $Y$, van Breemen RB, Bolton JL. The major metabolite of equilin, 4-hydroxyequilin, autoxidizes to an $o$-quinone which isomerizes to the potent cytotoxin 4-hydroxyequilenin-o-quinone. Chem Res Toxicol. 1999; 12(2):204-13.

48. Zhang N, Ding S, Kolbanovskiy A, Shastry A, Kuzmin VA, Bolton $J L$, Patel DJ, Broyde S, Geacintov NE. NMR and computational studies of stereoisomeric equine estrogen-derived DNA cytidine adducts in oligonucleotide duplexes: opposite orientations of diastereomeric forms. Biochemistry. 2009; 48(30):7098-109.

49. Okahashi Y, Iwamoto T, Suzuki N, Shibutani S, Sugiura S, Itoh S, Nishiwaki T, Ueno S, Mori T. Quantitative detection of 4-hydroxyequilenin-DNA adducts in mammalian cells using an immunoassay with a novel monoclonal antibody. Nucleic Acids Res. 2010; 38(12):e133.

50. Dezhurov SV, Khodyreva SN, Plekhanova ES, Lavrik OI. A new highly efficient photoreactive analogue of dCTP. Synthesis, characterization, and application in photoaffinity modification of DNA binding proteins. Bioconjug Chem. 2005; 16(1):215-22.

51. DellaVecchia MJ, Croteau DL, Skorvaga M, Dezhurov SV, Lavrik OI, Van Houten B. Analyzing the handoff of DNA from UvrA to UvrB utilizing DNA-protein photoaffinity labeling. $J$ Biol Chem. 2004; 279(43):45245-56.

52. Maltseva EA, Rechkunova NI, Gillet LC, Petruseva IO, Scharer $O D$, Lavrik OI. Crosslinking of the NER damage recognition proteins XPC-HR23B, XPA and RPA to photoreactive probes that mimic DNA damages. Biochim Biophys Acta. 2007; 1770 (5):781-9.

53. Rechkunova NI, Lavrik OI. Nucleotide excision repair in higher eukaryotes: mechanism of primary damage recognition in global genome repair. Subcell Biochem. 2010; 50:251-77.

54. Evdokimov A, Petruseva I, Tsidulko A, Koroleva L, Serpokrylova I, Silnikov $V$, Lavrik $O$. New synthetic substrates of mammalian nucleotide excision repair system. Nucleic Acids Res. 2013; 41(12):e123. 
55. Reardon JT, Sancar A. Repair of DNA-polypeptide crosslinks by human excision nuclease. Proc Natl Acad Sci USA. 2006; 103 (11):4056-61.

56. Huang JC, Sancar A. Determination of minimum substrate size for human excinuclease. J Biol Chem. 1994; 269(29):19034-40.

57. Biggerstaff $M$, Robins $P$, Coverley D, Wood RD. Effect of exogenous DNA fragments on human cell extract-mediated DNA repair synthesis. Mutat Res. 1991; 254(3):217-24.

58. Buterin T, Hess MT, Gunz D, Geacintov NE, Mullenders LH, Naegeli $H$. Trapping of DNA nucleotide excision repair factors by nonrepairable carcinogen adducts. Cancer Res. 2002; 62 (15):4229-35.

59. Hansson J, Wood RD. Repair synthesis by human cell extracts in DNA damaged by cis- and trans-diamminedichloroplatinum (II). Nucleic Acids Res. 1989; 17(20):8073-91.

60. Heiger-Bernays WJ, Essigmann JM, Lippard SJ. Effect of the antitumor drug cis-diamminedichloroplatinum(II) and related platinum complexes on eukaryotic DNA replication. Biochemistry. 1990; 29(36):8461-6.

61. Hess MT, Gunz D, Naegeli H. A repair competition assay to assess recognition by human nucleotide excision repair. Nucleic Acids Res. 1996; 24(5):824-8.

62. Sibghatullah, Husain I, Carlton W, Sancar A. Human nucleotide excision repair in vitro: repair of pyrimidine dimers, psoralen and cisplatin adducts by HeLa cell-free extract. Nucleic Acids Res. 1989; 17(12):4471-84.

63. Araki M, Masutani C, Takemura M, Uchida A, Sugasawa K, Kondoh J, Ohkuma Y, Hanaoka F. Centrosome protein centrin $2 /$ caltractin 1 is part of the xeroderma pigmentosum group $\mathrm{C}$ complex that initiates global genome nucleotide excision repair. J Biol Chem. 2001; 276(22):18665-72.

64. Huang JC, Svoboda DL, Reardon JT, Sancar A. Human nucleotide excision nuclease removes thymine dimers from DNA by incising the $22^{\text {nd }}$ phosphodiester bond $5^{\prime}$ and the $6^{\text {th }}$ phosphodiester bond 3 ' to the photodimer. Proc Natl Acad Sci USA. 1992; 89 (8):3664-8.

65. Svoboda DL, Taylor JS, Hearst JE, Sancar A. DNA repair by eukaryotic nucleotide excision nuclease. Removal of thymine dimer and psoralen monoadduct by HeLa cell-free extract and of thymine dimer by Xenopus laevis oocytes. J Biol Chem. 1993; 268(3):1931-6.

66. Szymkowski DE, Yarema K, Essigmann JM, Lippard SJ, Wood $R D$. An intrastrand $\mathrm{d}(\mathrm{GpG})$ platinum crosslink in duplex M13 DNA is refractory to repair by human cell extracts. Proc Natl Acad Sci USA. 1992; 89(22):10772-6.

67. Hansson J, Munn M, Rupp WD, Kahn R, Wood RD. Localization of DNA repair synthesis by human cell extracts to a short region at the site of a lesion. J Biol Chem. 1989; 264(36):21788-92.

68. Koehl P, Burnouf D, Fuchs RP. Construction of plasmids containing a unique acetylaminofluorene adduct located within a mutation hot spot. A new probe for frameshift mutagenesis. $\mathrm{J} \mathrm{Mol}$ Biol. 1989; 207(2):355-64.

69. Thorel F, Constantinou A, Dunand-Sauthier I, Nouspikel T, Lalle $P$, Raams A, Jaspers NG, Vermeulen W, Shivji MK, Wood RD, Clarkson $S G$. Definition of a short region of XPG necessary for TFIIH interaction and stable recruitment to sites of UV damage. Mol Cell Biol. 2004; 24(24):10670-80.

70. Sugasawa K, Akagi J, Nishi R, Iwai S, Hanaoka F. Two-step recognition of DNA damage for mammalian nucleotide excision repair: Directional binding of the XPC complex and DNA strand scanning. Mol Cell. 2009; 36(4):642-53.

71. Roche Y, Zhang D, Segers-Nolten GM, Vermeulen W, Wyman C, Sugasawa K, Hoeijmakers J, Otto C. Fluorescence correlation spectroscopy of the binding of nucleotide excision repair protein
XPC-hHr23B with DNA substrates. J Fluoresc. 2008; 18(5): 987-95.

72. Yeo JE, Khoo A, Fagbemi AF, Scharer OD. The efficiencies of damage recognition and excision correlate with duplex destabilization induced by acetylaminofluorene adducts in human nucleotide excision repair. Chem Res Toxicol. 2012; 25(11):2462-8.

73. Guggenheim ER, Xu D, Zhang CX, Chang PV, Lippard SJ. Photoaffinity isolation and identification of proteins in cancer cell extracts that bind to platinum-modified DNA. Chembiochem. 2009; 10(1):141-57.

74. Evdokimov AN, Tsidulko AYu, Petruseva IO, Koroleva LS, Serpokrylova IYu, Silnikov VN, Lavrik OI. Synthesis of model DNA and their application as substrates of nucleotide excision repair. Biopolym. Cell. 2012; 28(3):212-7.

75. Hess MT, Gunz D, Luneva N, Geacintov NE, Naegeli H. Base pair conformation-dependent excision of benzo[a]pyrene diol epoxide-guanine adducts by human nucleotide excision repair enzymes. Mol Cell Biol. 1997; 17(12):7069-76.

76. Todd RC, Lippard SJ. Consequences of cisplatin binding on nucleosome structure and dynamics. Chem Biol. 2010; 17(12): 1334-43.

77. Fei J, Kaczmarek N, Luch A, Glas A, Carell T, Naegeli H. Regulation of nucleotide excision repair by UV-DDB: prioritization of damage recognition to internucleosomal DNA. PLoS Biol. 2011; 9(10): 1001183.

78. Huang JC, Hsu DS, Kazantsev A, Sancar A. Substrate spectrum of human excinuclease: repair of abasic sites, methylated bases, mismatches and bulky adducts. Proc Natl Acad Sci USA. 1994; 91(25):12213-17.

79. Petruseva IO, Tikhanovich IS, Chelobanov BP, Lavrik OI. RPA repair recognition of DNA containing pyrimidines bearing bulky adducts. J Mol Recognit. 2008; 21(3):154-62.

80. Wlassoff WA, Dobrikov MI, Safronov IV, Dudko RY, Bogachev VS, Kandaurova VV, Shishkin GV, Dymshits GM, Lavrik OI. Synthesis and characterization of (d)NTP derivatives substituted with residues of different photoreagents. Bioconjug Chem. 1995; 6 (4):352-60.

81. Kolpashchikov DM, Zakharenko AL, Dezhurov SV, Rechkunova NI, Khodyreva SN, Degtiarev S, Litvak VV, Lavrik OI. New reagents for affinity modification of biopolymers. Photoaffinity modification of Tte-DNA polymerase. Bioorg Khim. 1999; 25 (2):129-36.

82. Neher TM, Rechkunova NI, Lavrik OI, Turchi JJ. Photo-crosslinking of XPC-Rad23B to cisplatin-damaged DNA reveals contacts with both strands of the DNA duplex and spans the DNA adduct. Biochemistry. 2010; 49(4):669-78.

83. Khodyreva SN, Lavrik OI. Photoaffinity labeling technique for studying DNA replication and DNA repair. Curr Med Chem. 2005; 12(6):641-55.

84. Knorre DG, Godovikova TS. Photoaffinity labeling as an approach to study supramolecular nucleoprotein complexes. FEBS Lett. 1998; 433(1-2):9-14.

85. Zakharenko AL, Khodyreva SN, Rechkunova NI, Safronov IV, Pyshnyi DV, Degtyarev SK, Lavrik OI. Photoaffinity labeling of DNA polymerase from Thermus thermophilus and DNA template by photoreactive analogs of dCTP. Biochemistry (Mosc). 1998; 63(8):929-34.

86. Nguyen HK, Auffray P, Asseline U, Dupret D, Thuong NT. Modification of DNA duplexes to smooth their thermal stability independently of their base content for DNA sequencing by hybridization. Nucleic Acids Res. 1997; 25(15):3059-65.

87. Meisenheimer KM, Koch TH. Photocross-linking of nucleic acids to associated proteins. Crit Rev Biochem Mol Biol. 1997; 32(2):101-40. 
88. Schweizer U, Hey T, Lipps $G$, Krauss $G$. Photocrosslinking locates a binding site for the large subunit of human replication protein A to the damaged strand of cisplatin-modified DNA. Nucleic Acids Res. 1999; 27(15):3183-9.

89. Petruseva IO, Tikhanovich IS, Maltseva EA, Safronov IV, Lavrik $O I$. Photoactivated DNA analogs of substrates of the nucleotide excision repair system and their interaction with proteins of NER-competent HeLa cell extract. Biochemistry (Mosc). 2009; 74(5):491-501.

90. Krasikova YS, Rechkunova NI, Maltseva EA, Petruseva IO, Lavrik $O I$. Localization of xeroderma pigmentosum group A protein and replication protein A on damaged DNA in nucleotide excision repair. Nucleic Acids Res. 2011; 38(22): 8083-94.

91. Krasikova YS, Rechkunova NI, Maltseva EA, Petruseva IO, Silnikov VN, Zatsepin TS, Oretskaya TS, Scharer OD, Lavrik OI. Interaction of nucleotide excision repair factors XPC-HR23B, XPA, and RPA with damaged DNA. Biochemistry (Mosc). 2008; 73 (8):886-96.

92. Min JH, Pavletich NP. Recognition of DNA damage by the Rad4 nucleotide excision repair protein. Nature. 2007; 449(7162): 570-5.

93. Krasikova YS, Rechkunova NI, Maltseva EA, Pestryakov PE, Petruseva IO, Sugasawa K, Chen X, Min JH, Lavrik OI. Comparative analysis of interaction of human and yeast DNA damage recognition complexes with damaged DNA in nucleotide excision repair. J Biol Chem. 2013; 288(15):10936-47.

94. Liu Y, Yang Z, Utzat CD, Liu Y, Geacintov NE, Basu AK, Zou Y. Interactions of human replication protein A with single-stranded DNA adducts. Biochem J. 2005; 385(Pt 2):519-26.

95. de Laat WL, Appeldoorn E, Sugasawa K, Weterings E, Jaspers $N G$, Hoeijmakers $J H$. DNA-binding polarity of human replication protein A positions nucleases in nucleotide excision repair. Genes Dev. 1998; 12(16):2598-609.

96. Maltseva EA, Rechkunova NI, Petruseva IO, Vermeulen W, Scharer OD, Lavrik OI. Crosslinking of nucleotide excision repair proteins with DNA containing photoreactive damages. Bioorg Chem. 2008; 36(2):77-84.

97. Bergink $S$, Toussaint W, Luijsterburg MS, Dinant C, Alekseev $S$ Hoeijmakers JH, Dantuma NP, Houtsmuller AB, Vermeulen W. Recognition of DNA damage by XPC coincides with disruption of the XPC-RAD23 complex. J Cell Biol. 2012;196(6):681-8.

98. Anin MF, Leng $M$. Distortions induced in double-stranded oligonucleotides by the binding of cis- or trans-diammine-dichloro platinum (II) to the d(GTG) sequence. Nucleic Acids Res. 1990; 18(15):4395-400.

99. Bellon SF, Coleman JH, Lippard SJ. DNA unwinding produced by site-specific intrastrand cross-links of the antitumor drug $\mathrm{cis}$ diamminedichloroplatinum(II). Biochemistry. 1991; 30(32): 8026-35.

100. van Garderen CJ, van Houte LP. The solution structure of a DNA duplex containing the cis-Pt(NH3)2[d(-GTG-)-N7(G),N7(G)] adduct, as determined with high-field NMR and molecular mechanics/dynamics. Eur J Biochem. 1994; 225(3):1169-79.

101. Calsou P, Frit P, Salles B. Double strand breaks in DNA inhibit nucleotide excision repair in vitro. J Biol Chem. 1996; 271(44): 27601-7.

102. Evdokimov AN, Petruseva IO, Pestryakov PE, Lavrik OI. Photoactivated DNA analogs of substrates of the nucleotide excision repair system and their interaction with proteins of NER-competent extract of HeLa cells. Synthesis and application of long model DNA. Biochemistry (Mosc). 2011; 76(1):157-66.

103. Huang JC, Zamble DB, Reardon JT, Lippard SJ, Sancar A. HMG-domain proteins specifically inhibit the repair of the major DNA adduct of the anticancer drug cisplatin by human excision nuclease. Proc Natl Acad Sci USA. 1994; 91(22):10394-8.

104. Langie SA, Cameron KM, Waldron KJ, Fletcher KP, von Zglinicki T, Mathers JC. Measuring DNA repair incision activity of mouse tissue extracts towards singlet oxygen-induced DNA damage: a comet-based in vitro repair assay. Mutagenesis. 2011; 26(3):461-71.

105. Araujo SJ, Tirode F, Coin F, Pospiech H, Syvaoja JE, Stucki M, Hubscher U, Egly JM, Wood RD. Nucleotide excision repair of DNA with recombinant human proteins: definition of the minimal set of factors, active forms of TFIIH, and modulation by CAK. Genes Dev. 2000; 14(3):349-59.

106. Shell SM, Hawkins EK, Tsai MS, Hlaing AS, Rizzo CJ, Chazin $W J$. Xeroderma pigmentosum complementation group $\mathrm{C}$ protein (XPC) serves as a general sensor of damaged DNA. DNA Repair (Amst). 2013; 12(11):947-53.

107. Vaisman A, McDonald JP, Huston D, Kuban W, Liu L, Van Houten $B$, Woodgate $R$. Removal of misincorporated ribonucleotides from prokaryotic genomes: an unexpected role for nucleotide excision repair. PLoS Genet. 2013; 9(11):e1003878.

Received 15.01.14 